\title{
Productivity of pigs of conservation breeds in terms of selected gene polymorphisms
}

\author{
ANNA NIENARTOWICZ-ZDROJEWSKA, ZBIGNIEW SOBEK, JANUSZ T. BUCZYŃSKI*, \\ ANNA KONIECZKA*, JOLANTA RÓŻAŃSKA-ZAWIEJA
}

\begin{abstract}
Department of Genetics and Animal Breeding, *Department of Pig Breeding and Production, Faculty of Veterinary Medicine and Animal Science, Poznan University of Life Sciences, ul. Wołyńska 33, 60-637 Poznań
\end{abstract}

Nienartowicz-Zdrojewska A., Sobek Z., Buczyński J. T., Konieczka A., Różańska-Zawieja J. Productivity of pigs of conservation breeds in terms of selected gene polymorphisms

\section{Summary}

The material for the analyses comprised blood samples collected from 65 Zlotnicka Spotted (Zlp) sows and 43 Zlotnicka White (Zlb) sows born and kept in two herds in Wielkopolska. While analysing reproductive, fattening and slaughter traits, information was collected on 290 litters, including 180 litters of Zlp sows and 110 litters of Zlb sows. Intravital measurements were taken using a Piglog 105 for the evaluation of the mean backfat thickness, lean meat content and loin eye thickness. The aim of the research was to determine the effect of selected genotypes on reproductive, fattening and carcass performance traits of the two indigenous pig breeds (Zlotnicka White and Zlotnicka Spotted), kept and bred in Poland.

The frequency of RYR1 genotypes indicates that the number of animals with the RYRTT genotype carrying a mutation in the RYR1 gene was low in the Zlotnicka breeds. In the herd of Zlb sows, a statistically significant negative effect of the RYRCT genotype on piglet wastage up to 21 days of age was found. The highest wastage rate was recorded in the group of heterozygotes. The frequency of the genotypes indicates that the DD genotype typical of animals with polymorphism in the GH/MspI gene occurred rarely in the analysed population of the Zlotnicka breeds. A statistically significant effect of the GH/MspI genotype on litter weight at 21 days of age was observed in the population of the Zlb sows. The heaviest piglets were born to sows with the DD genotype, while the lightest piglets were born to sows with the CC genotype. The frequency of the LEP genotypes indicates that the number of animals with the TT genotype was very low in the population of the Zlb pigs. No animal with the TT genotype was found in the ZIp herd.

Keywords: Zlotnicka White, Zlotnicka Spotted, LEP, RYR, GH

The dynamic development of research techniques in molecular genetics resulted in a number of studies on gene function in livestock $(7,8)$. An example of a big-effect gene is the already well investigated and described ryanodine receptor (RYR1) gene, also known as the halothane gene (HAL), connected with porcine stress vulnerability $(13,20)$.

One of many genes influencing reproductive traits is the growth hormone - GH (12), which stimulates cell growth and differentiation. It plays a crucial role in gonad development, in male and female reproductive cell production and in embryo development (14).

The leptin gene (LEP), which influences animal metabolism, and its receptor gene (LEPR), found in the ovaries, testes, placenta, hypothalamus and pituitary gland of animals, affect embyro development and placenta physiology $(5,21)$. Studies on the influence of genes on productive traits in pigs have been conducted for many years. Additionally, RYR1, GH and LEP polymorphism studies on indigenous breed populations make it possible to create a unique genetic animal model kept as a genetic reserve $(1-4,9)$.

The aim of this research was to determine the effect of selected genotypes on the reproductive, fattening and carcass performance traits of two indigenous pig breeds, Zlotnicka White and Zlotnicka Spotted, kept and bred in Poland.

\section{Material and methods}

Material for analyses comprised blood collected from 65 sows of the Zlotnicka Spotted breed (zlp) and 43 sows of the Zlotnicka White breed (zlb), born and kept in two herds in the Wielkopolska region, with only one breed kept in each herd. When analysing reproductive, fattening and slaughter traits, information was collected on 290 litters, including 180 litters of the Zlotnicka Spotted sows and 110 litters of the Zlotnicka White sows, born in the years 2006-2010. 
Identification of genotypes was based on PCR-RFLP analysis. It is known that the most common mutation in this gene is C1843T. Therefore, these studies were designed to detect or exclude it in the gene RYR1. For PCR-RFLP analysis, the restriction enzyme HhaI was used. The presence of two polymorphisms of the growth hormone gene. GH was also determined (using the enzymes HaeII and MspI).

In the case of genetic research on leptin frequency of genotypes LEP and the attendance of one polymorphism of this gene: A2845T, which was made using the enzyme $\mathrm{XbaI}$ were determined.

When analysing fattening and slaughter performance traits of sows, measurements were taken in vivo with the use of a Piglog 105 apparatus to record the mean backfat thickness from 2 measurements $(\mathrm{mm})$, the meat content in the carcass $(\%)$ and the loin eye height $(\mathrm{mm})$. Calculations were performed with the SAS statistical package (18), applying the linear models given below:

1) linear model for reproductive traits:

where:

$$
\mathrm{Y}_{\mathrm{ijk}}=\mu+\mathrm{g}_{\mathrm{i}}+\mathrm{m}_{\mathrm{j}}+\mathrm{r}_{\mathrm{k}}+\mathrm{e}_{\mathrm{ijk}}
$$

$\mathrm{Y}_{\mathrm{ijk}}$ - expected value,

$\mu$ - overall average,

$\mathrm{g}_{i},-$ a random effect of $\mathrm{i}-\mathrm{RYR} 1$ genotype, where $\mathrm{i}=1,2,3$; $\mathrm{m}_{\mathrm{j}}-\mathrm{a}$ random effect of $\mathrm{j}$-litter of each sow, where $\mathrm{j}=1$,

$2, \ldots, 10$,

$r_{k}-$ random effect of $\mathrm{k}$ - litter breed, where $\mathrm{k}=1,2,3,4$;

$\mathrm{e}_{\mathrm{ij}, \mathrm{k}}$ - the effect of random error.

2) model for the analysis of variance of fattening and slaughter traits:

where:

$$
\mathrm{Y}_{\mathrm{ijk}}=\mu+\mathrm{g}_{\mathrm{i}}+\mathrm{r}_{\mathrm{j}}+\mathrm{e}_{\mathrm{ijk}}
$$

$\mathrm{Y}_{\mathrm{ijk}}$ - the expected value of the characteristic,

$\mu$ - overall average,

$\mathrm{g}_{\mathrm{i}}-\mathrm{a}$ random effect of $\mathrm{i}-\mathrm{RYR} 1$ genotype, where $i=1,2,3$;

$r_{j}-a$ random effect of $j-$ litter breed, where $\mathrm{j}=1,2$,

$\mathrm{e}_{\mathrm{ijk}}-$ the effect of random error.

To convert random values, probit transformation was used (23).

\section{Results and discussion}

When investigating the frequency of the RYR1 genotypes, it was found that $45 \%$ of Zlotnicka White sows had the CC genotype, $40 \%$ the CT genotype, and $15 \%$ of the animals had the TT genotype. Among the Zlotnicka Spotted sows, these frequencies were as follows: $56 \%$, $29 \%$ and $15 \%$ for CC, CT and TT, respectively.

Fattening and slaughter performance traits measured in vivo included standardized daily body weight gains $(\mathrm{g})$, the mean backfat thickness from 2 measurements $(\mathrm{mm})$, the meat content in the car-

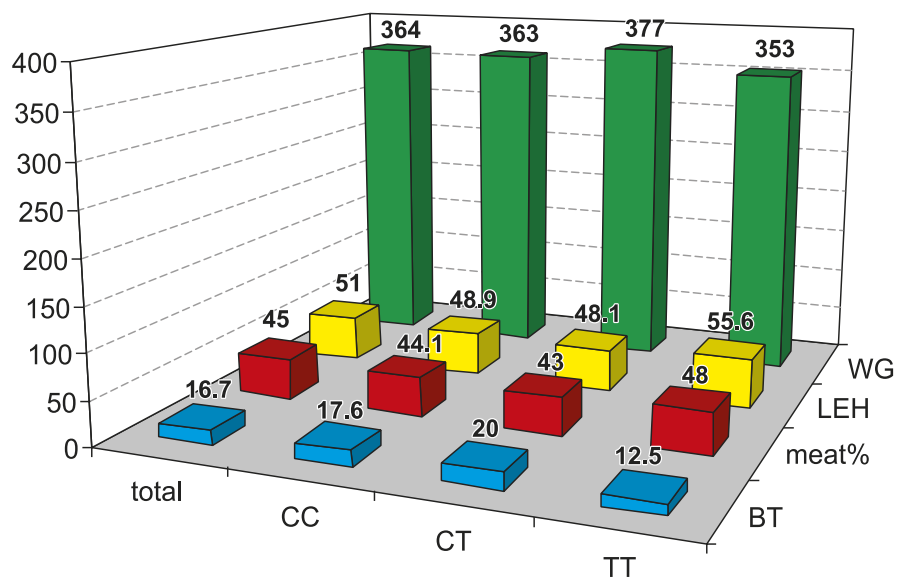

Fig. 1. Mean values of fattening and slaughter performance traits of Zlotnicka White and Zlotnicka Spotted sows with different RYR1 genotypes

Explanations: BT - backfat thickness; meat $\%$ - percentage meat content; LEH - loin eye height (mm); WG - weigh gain

cass $(\%)$ and the loin eye height $(\mathrm{mm})$ in Zlotnicka White and Zlotnicka Spotted pigs with a specific genotype. Figure 1 presents mean values of the fattening and slaughter performance traits for sows with different RYR1 genotypes. Table 1 presents mean values of the reproductive performance traits for sows of the Zlotnicka White and Zlotnicka Spotted breeds, respectively.

Polymorphism within the RYR1 gene did not have a statistically significant effect on daily weight gain values. The highest value of the loin eye diameter was recorded in pigs with the TT genotype $(55.6 \mathrm{~mm})$, and the lowest in the CT heterozygotes $(48.1 \mathrm{~mm})$, with

Tab. 1. Mean values of reproductive performance traits in Zlotnicka White (Zlb)

\begin{tabular}{|c|c|c|c|c|c|c|c|}
\hline \multirow{3}{*}{ Trait } & \multirow{3}{*}{ Statistics } & \multicolumn{6}{|c|}{ Genotype } \\
\hline & & \multicolumn{3}{|c|}{ Zlotnicka White } & \multicolumn{3}{|c|}{ Zlotnicka Spotted } \\
\hline & & CC & CT & $\mathrm{TT}$ & CC & СT & $\mathrm{TT}$ \\
\hline $\begin{array}{l}\text { Number of piglets } \\
\text { born alive }\end{array}$ & $\begin{array}{c}\mathbf{X}^{*} \\
\mathbf{S D}^{* *} \\
\mathbf{C V}^{* * *}\end{array}$ & $\begin{array}{r}10.66 \\
2.69 \\
25.25\end{array}$ & $\begin{array}{r}10.67 \\
2.64 \\
24.75\end{array}$ & $\begin{array}{r}9.87 \\
2.39 \\
24.28\end{array}$ & $\begin{array}{r}8.33 \\
1.82 \\
21.94\end{array}$ & $\begin{array}{r}8.57 \\
1.92 \\
22.39\end{array}$ & $\begin{array}{r}7.83 \\
2.82 \\
36.03\end{array}$ \\
\hline $\begin{array}{l}\text { Number of piglets } \\
\text { in } 21^{1 \text { t }} \text { day of life }\end{array}$ & $\begin{array}{l}X \\
\text { SD } \\
\text { CV }\end{array}$ & $\begin{array}{r}8.93 \\
2.07 \\
23.23\end{array}$ & $\begin{array}{r}8.59 \\
2.23 \\
26.02\end{array}$ & $\begin{array}{r}8.61 \\
2.15 \\
25.06\end{array}$ & $\begin{array}{r}7.81 \\
2.07 \\
26.59\end{array}$ & $\begin{array}{r}8.33 \\
1.88 \\
22.58\end{array}$ & $\begin{array}{r}7.58 \\
2.67 \\
35.32\end{array}$ \\
\hline $\begin{array}{l}\text { Number of gilts } \\
\text { in } 21^{\text {st }} \text { day of life }\end{array}$ & $\begin{array}{l}X \\
\text { SD } \\
\text { CV }\end{array}$ & $\begin{array}{r}4.17 \\
1.68 \\
40.41\end{array}$ & $\begin{array}{r}4.31 \\
1.51 \\
35.14\end{array}$ & $\begin{array}{r}4.38 \\
1.94 \\
44.27\end{array}$ & $\begin{array}{r}3.86^{\mathrm{a}} \\
1.58 \\
41.08\end{array}$ & $\begin{array}{c}4.27^{\mathrm{b}} \\
1.56 \\
36.66\end{array}$ & $\begin{array}{r}3.16^{c} \\
1.11 \\
35.19\end{array}$ \\
\hline $\begin{array}{l}\text { Number of boars } \\
\text { in } 21^{\text {st }} \text { day of life }\end{array}$ & $\begin{array}{l}X \\
\text { SD } \\
\text { CV }\end{array}$ & $\begin{array}{r}4.76 \\
1.69 \\
35.61\end{array}$ & $\begin{array}{r}4.28 \\
1.89 \\
44.11\end{array}$ & $\begin{array}{r}4.23 \\
1.76 \\
41.81\end{array}$ & $\begin{array}{r}3.95 \\
1.56 \\
39.66\end{array}$ & $\begin{array}{r}4.06 \\
1.56 \\
38.41\end{array}$ & $\begin{array}{r}4.41 \\
1.83 \\
41.47\end{array}$ \\
\hline $\begin{array}{l}\text { Piglet wastage } \\
(\%)\end{array}$ & $\begin{array}{l}X \\
\text { SD } \\
\text { CV }\end{array}$ & $\begin{array}{r}13.93^{\mathrm{a}} \\
15.66 \\
112.44\end{array}$ & $\begin{array}{l}17.64^{b} \\
16.83 \\
95.43\end{array}$ & $\begin{array}{r}11.89^{c} \\
12.70 \\
106.85\end{array}$ & $\begin{array}{r}6.37^{\mathrm{a}} \\
13.30 \\
208.69\end{array}$ & $\begin{array}{r}2.64^{\mathrm{b}} \\
5.56 \\
210.41\end{array}$ & $\begin{array}{r}2.63^{\mathrm{c}} \\
4.82 \\
183.15\end{array}$ \\
\hline $\begin{array}{l}\text { Litter weight } \\
\text { at day } 21(\mathrm{~kg})\end{array}$ & $\begin{array}{l}X \\
\text { SD } \\
\text { CV }\end{array}$ & $\begin{array}{l}42.91^{a} \\
21.39 \\
49.86\end{array}$ & $\begin{array}{r}31.96^{b} \\
8.22 \\
25.72\end{array}$ & $\begin{array}{r}31.42^{\mathrm{c}} \\
7.02 \\
22.34\end{array}$ & $\begin{array}{l}28.16^{a} \\
12.77 \\
45.36\end{array}$ & $\begin{array}{r}41.65^{b} \\
7.37 \\
17.70\end{array}$ & $\begin{array}{r}53.60^{\complement} \\
8.34 \\
15.56\end{array}$ \\
\hline
\end{tabular}
sows and Zlotnicka Spotted (Zlp) sows with different RYR1 genotypes

Explanations: $* \mathrm{X}-$ mean; $* * \mathrm{SD}-$ standard deviation; $* * * \mathrm{CV}-$ coefficient of variation. Small letters $(\mathrm{a}, \mathrm{b}, \mathrm{c})$ describe statistically significant differences $(\mathrm{P} \leq 0.05)$, and capital letters $(\mathrm{A}, \mathrm{B}, \mathrm{C})$ describe highly statistically significant differences $(\mathrm{P} \leq 0.01)$ 
the differences between the above mentioned groups being statistically significant. A similar difference was observed for meat contents in the carcass. The greatest leanness (48\%) and the lowest backfat thickness $(12.5 \mathrm{~mm})$ were found in pigs with the TT genotype. The lowest leanness was observed in the CC homozygotes. The greatest backfat thickness was recorded in the CT heterozygotes. Differences between the abovementioned means were statistically significant.

Skrlep et al. (19) analysed 257 carcasses of hybrids (Landrace crossed with paternal components: Pietrain and Hampshire). They did not find a significant effect of the RYR1 polymorphisms on dressing percentage, but observed a significant effect of these polymorphisms on the quality of meat in the carcass.

With regard to the reproductive performance traits of Zlotnicka White sows and Zlotnicka Spotted sows (Tab. 1), it was found that the effect of a specific RYR1 genotype on these traits differed in the two breeds. An example is the litter weight at day 21, which in Zlotnicka White sows with the CC genotype was the highest (42.9), whereas in Zlotnicka Spotted sows the lowest (28.2). A markedly higher piglet wastage percentage was recorded for Zlotnicka White pigs than for Zlotnicka Spotted sows, with differences between sows with a specific genotype being non-significant for Zlotnicka Spotted sows. For Zlotnicka White sows, the lowest wastage percentage $(11.9 \%)$ was found in the TT homozygotes, and the level was significantly lower than the wastage rates for heterozygotes $(\mathrm{CT})$. The number of piglets at day 21 , similarly as the number of boar piglets and the number of gilts at day 21 , did not differ between sows with different genotypes, but slightly lower values were found in Zlotnicka Spotted sows.

When investigating reproductive performance traits, Buczyński et al. (1-3) found that Zlotnicka White sows with the CT genotype of the RYR1 gene produced on average 0.5 piglets more than sows with the TT genotype. A study by Matoušek et al. (13) confirmed better fertility parameters in the CT heterozygotes.

The frequency of genotypes for the two polymorphisms of the growth hormone gene $(\mathrm{GH})$ was determined with the use of the MspI i HaelII enzymes. The frequency of $\mathrm{GH}$, identified using the MspI enzyme, was as follows: among Zlotnicka White sows, 53\% had the CC genotype, $33 \%$ had the CD genotype and $14 \%$ had the DD genotype, whereas in Zlotnicka Spotted sows the distribution of genotypes was slightly different:

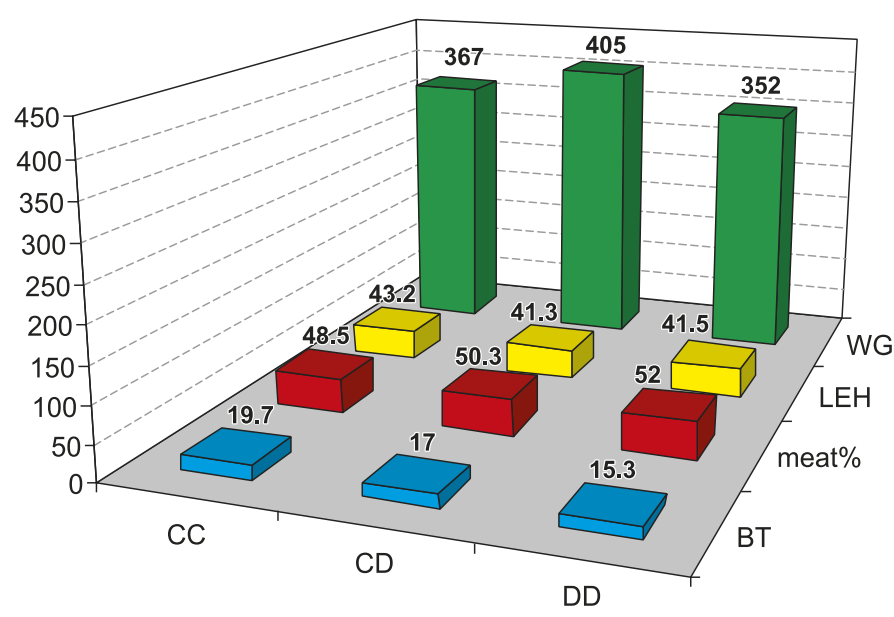

Fig. 2. Mean values of fattening and slaughter performance traits in Zlotnicka White and Zlotnicka Spotted sows with different GH/MspI genotypes

Explanations: as in Fig. 1.

$\mathrm{CC}$ was found in $43 \%$ of animals, $35 \%$ were heterozygotes, and $22 \%$ were DD homozygotes.

Since the fattening, slaughter and reproductive performance traits of Zlotnicka White and Zlotnicka Spotted sows with different genotypes were similar, the analysis of variance was performed jointly for Zlotnicka White and Zlotnicka Spotted sows.

Figure 2 presents the mean values of the fattening performance traits for Zlotnicka White and Zlotnicka Spotted sows, differing in the GH/MspI polymorphism. The lowest values of daily weight gains and the lowest value of backfat thickness, as well as the highest meat content in the carcass, were recorded in sows with the DD genotype. However, differences between means turned out to be statistically non-significant.
Tab. 2. Mean values of reproductive performance traits in Zlotnicka White (Zlb) sows and Zlotnicka Spotted (Zlp) sows with different GH/MspI genotypes

\begin{tabular}{|c|c|c|c|c|c|c|c|}
\hline \multirow{3}{*}{ Trait } & \multirow{3}{*}{ Statistics } & \multicolumn{6}{|c|}{ Genotype } \\
\hline & & \multicolumn{3}{|c|}{ Zlotnicka White } & \multicolumn{3}{|c|}{ Zlotnicka Spotted } \\
\hline & & CC & CD & DD & CC & CD & DD \\
\hline $\begin{array}{l}\text { Number of piglets } \\
\text { born alive }\end{array}$ & $\begin{array}{c}\mathbf{X}^{*} \\
\mathbf{S D}^{* *} \\
\mathbf{C V}^{* * *}\end{array}$ & $\begin{array}{r}10.09 \\
2.34 \\
23.20\end{array}$ & $\begin{array}{r}11.02 \\
2.96 \\
26.90\end{array}$ & $\begin{array}{r}10.87 \\
2.67 \\
24.61\end{array}$ & $\begin{array}{r}8.42 \\
2.04 \\
24.21\end{array}$ & $\begin{array}{r}8.35 \\
2.11 \\
25.28\end{array}$ & $\begin{array}{r}8.19 \\
1.47 \\
17.96\end{array}$ \\
\hline $\begin{array}{l}\text { Number of piglets } \\
\text { in } 21^{\text {st }} \text { day of life }\end{array}$ & $\begin{array}{l}X \\
\text { SD } \\
\text { CV }\end{array}$ & $\begin{array}{r}8.37 \\
2.25 \\
26.90\end{array}$ & $\begin{array}{r}9.13 \\
2.11 \\
23.13\end{array}$ & $\begin{array}{r}9.13 \\
1.76 \\
19.23\end{array}$ & $\begin{array}{r}8.09 \\
2.19 \\
27.07\end{array}$ & $\begin{array}{r}7.89 \\
2.22 \\
28.18\end{array}$ & $\begin{array}{r}7.75 \\
1.39 \\
17.94\end{array}$ \\
\hline $\begin{array}{l}\text { Number of gilts } \\
\text { in } 21^{1 t} \text { day of life }\end{array}$ & $\begin{array}{l}X \\
S D \\
C V\end{array}$ & $\begin{array}{r}4.37 \\
1.67 \\
38.27\end{array}$ & $\begin{array}{r}4.13 \\
1.81 \\
43.77\end{array}$ & $\begin{array}{r}4.23 \\
1.41 \\
33.22\end{array}$ & $\begin{array}{r}4.05 \\
1.66 \\
41.05\end{array}$ & $\begin{array}{r}3.89 \\
1.48 \\
38.01\end{array}$ & $\begin{array}{r}3.63 \\
1.54 \\
42.59\end{array}$ \\
\hline $\begin{array}{l}\text { Number of boars } \\
\text { in } 21^{\text {st }} \text { day of life }\end{array}$ & $\begin{array}{l}X \\
\text { SD } \\
\text { CV }\end{array}$ & $\begin{array}{c}4.00^{\mathrm{Bb}} \\
1.69 \\
42.24\end{array}$ & $\begin{array}{c}5.00^{\text {Aa }} \\
1.88 \\
37.62\end{array}$ & $\begin{array}{c}4.90^{\mathrm{ca}} \\
1.69 \\
34.46\end{array}$ & $\begin{array}{r}4.05 \\
1.63 \\
40.34\end{array}$ & $\begin{array}{r}4.00 \\
1.55 \\
38.73\end{array}$ & $\begin{array}{r}4.13 \\
1.67 \\
40.44\end{array}$ \\
\hline $\begin{array}{l}\text { Piglet wastage } \\
\text { (\%) }\end{array}$ & $\begin{array}{l}X \\
S D \\
C V\end{array}$ & $\begin{array}{l}16.05 \\
15.53 \\
96.97\end{array}$ & $\begin{array}{r}14.25 \\
16.45 \\
115.43\end{array}$ & $\begin{array}{r}13.39 \\
15.17 \\
113.33\end{array}$ & $\begin{array}{r}4.16 \\
9.43 \\
226.78\end{array}$ & $\begin{array}{r}5.31 \\
12.43 \\
234.30\end{array}$ & $\begin{array}{r}4.91 \\
9.42 \\
191.79\end{array}$ \\
\hline $\begin{array}{l}\text { Litter weight } \\
\text { at day } 21(\mathrm{~kg})\end{array}$ & $\begin{array}{l}X \\
\text { SD } \\
\text { CV }\end{array}$ & $\begin{array}{c}29.36^{\mathrm{a}} \\
8.98 \\
30.60\end{array}$ & $\begin{array}{l}37.50^{b} \\
10.84 \\
28.91\end{array}$ & $\begin{array}{l}46.80^{c} \\
21.76 \\
46.50\end{array}$ & $\begin{array}{c}29.40^{\mathrm{a}} \\
8.73 \\
29.60\end{array}$ & $\begin{array}{l}37.50^{b} \\
10.86 \\
28.80\end{array}$ & $\begin{array}{l}46.90^{\circ} \\
22.13 \\
31.20\end{array}$ \\
\hline
\end{tabular}

Explanations: as in Tab. 1. 
In terms of the reproductive performance traits of Zlotnicka White sows, females with the CC genotype differed highly significantly in the number of boar piglets reared to day 21 of life from sows that were CD heterozygotes and DD homozygotes. Litter weight at day 21 also differed highly significantly between sows with different $\mathrm{GH} / \mathrm{MspI}$ genotypes. A similar trend was observed for Zlotnicka Spotted sows (Tab. 2). Sows with the DD genotype had a statistically significantly higher litter weight at day 21.

The frequency of GH/HaeII genotypes in the population of Zlotnicka White sows amounted to $45 \%$ for the AA genotype, $30 \%$ for the AB heterozygotes and $25 \%$ for the BB homozygotes. Among Zlotnicka Spotted sows, the distribution of genotypes was $46 \%, 32 \%$ and $22 \%$ for $\mathrm{AA}, \mathrm{AB}$ and $\mathrm{BB}$, respectively.

Figure 3 presents the mean values of the selected fattening and slaughter performance traits for Zlotnicka White and Zlotnicka Spotted sows with different genotypes within the growth hormone gene GH/HaeII. The largest daily gains were noted for the heterozygous genotype AB. Growth in this group of sows amounted on average to $378 \mathrm{~g}$. The highest percentage of meatiness and the biggest eye fillet were found in the homozygous genotype AA. These differences were not statistically significant. With respect to reproductive traits, the best parameters were obtained, regardless of the breed, in sows with the genotype AA in relation to the $\mathrm{GH} / \mathrm{HaeII}$ gene.

Differences between sows with different genotypes in terms of the mean litter weight at day 21 and percentage wastage values were statistically highly significant, while differences in the number of live born piglets and piglets reared to day 21 proved to be statistically significant. Among other features, there were no statistically significant differences.

Rybarczyk et al. (16) determined a relationship of the polymorphism of the growth hormone gene $(\mathrm{GH})$ and the RYR1 genotypes with selected traits of carcass quality and leanness in 126 hybrid fatteners. For the population, the authors obtained the following frequencies: $\mathrm{GH} / \mathrm{MspI} \mathrm{A}=0.78$ and $\mathrm{B}=0.22 ; \mathrm{GH} / \mathrm{HaeII}$ $\mathrm{A}=0.86$ and $\mathrm{B}=0.14$. Moreover, no relationship was found between the GH polymorphism and meat quality or meat content in the carcass. Franco et al. (6), when analysing the GH polymorphism, observed that it was connected statistically significantly with backfat thickness and mean daily weight gains.

Kurył et al. (11) studied a total of 305 pigs of different breeds, including Zlotnicka Spotted. They found that the frequency of individual LEP variants and GH genotypes depended on the breed or line. Compared with the CT genotype, the TT genotype in the LEP locus was associated with a lower live weight, ham weight and fat content in ham. Moreover, the genotypes AA at locus GH/HaeII and BB at locus GH/MspI were the least advantageous in terms of the ham weight and

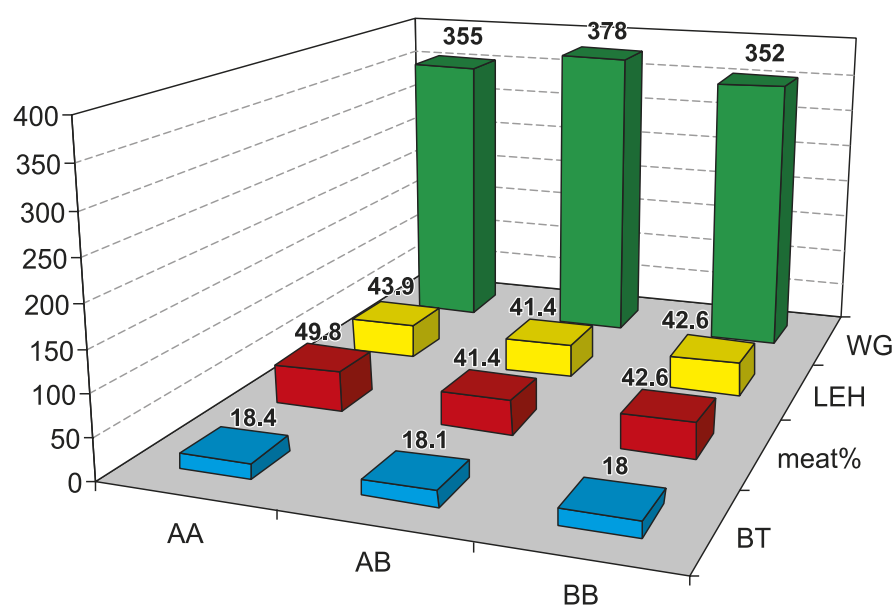

Fig. 3. Mean values of fattening and slaughter performance traits in Zlotnicka White and Zlotnicka Spotted sows with different GH/HaeII genotypes

Explanations: as in Fig. 1.

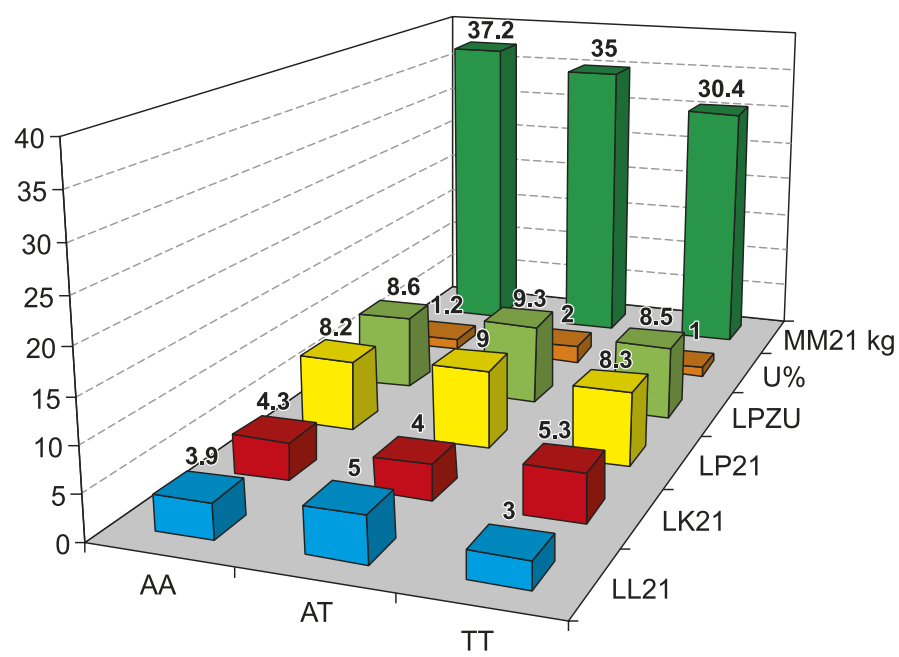

Fig. 4. Mean values of reproductive performance traits in Zlotnicka White sows with different LEP genotypes

Explanations: LL21 - number of gilts in $21^{\text {st }}$ day of life; LK21 number of boars in $21^{\text {st }}$ day of life; LP21 - number of piglets in $21^{\text {st }}$ day of life; LPZU - number of piglets born alive; $\mathrm{U} \%$ - piglet wastage $\%$; MM $21 \mathrm{~kg}$ - litter weight at day 21

meat content in the carcass, compared with the other genotypes in these loci. On the other hand, these genotypes were associated with a greater carcass length.

In a study by Rybarczyk (17), all the tested pigs had the TT genotype. Fatteners with genotypes GG G2728A and TT T3469C had a considerably high carcass leanness, at a level of $57 \%$, and $73.5 \%$ of them were classified to grades $\mathrm{S}$ and $\mathrm{E}$ of the EUROP system. Analysis of their meat quality showed that PSE meat accounted for only $4.8 \%$, at an optimal share of intramuscular fat.

Pripwai and Mekchay (15), when analysing 1361 litters of pigs from commercial crossing, found that heterozygotes within MspI showed a statistically significantly higher percentage of reared piglets in comparison to the $\mathrm{GH}$ homozygotes.

In the population analysed here, the frequency of three genotypes of the leptin gene (LEP) was deter- 
mined. It showed that, among the Zlotnicka White pigs, $74 \%$ of animals had the AA genotype, $16 \%$ were the AT heterozygotes, and 10\% were the TT homozygotes. Among Zlotnicka Spotted sows, 97.5\% had the AA genotype, $2.5 \%$ were heterozygous, and none was a TT homozygote, which probably results from the random sample collection and the relatively small number of data.

Figure 4 gives the mean values of reproductive performance traits for Zlotnicka White sows with different LEP genotypes. No statistically significant differences were found between sows with different genotypes in terms of the traits analysed. Because of the small number of Zlotnicka Spotted sows with genotypes differing in terms of the leptin gene, no further statistical analysis was performed.

The leptin gene is currently believed to have a broad spectrum of action in animals. Leptin is known to be an important factor in the regulation of fat reserves, feed uptake and body weight. It results from many studies conducted to date that leptin also serves several important roles in the regulation of reproductive functions (22). Kennes et al. (10) performed studies on Yorkshire, Landrace and Duroc pigs. The aim of their investigations was to find a relationship between the LEP gene polymorphisms, i.e. A2845T, T3996C, G2728A and T3469C, and pig production traits particularly important from the economic point of view. These analyses showed that the frequency of these LEP gene polymorphisms in pig populations is either very low or these polymorphisms are not found at all. A study by Kennes (10) confirmed that in the genotypes of animals examined, as well as in many other pig breeds, e.g. in populations of the Zlotnicka breeds, the frequencies of mutated LEP alleles were low.

The prevalence of genotypes RYR1 indicates 15 percent of the RYR (TT) individuals in the RYR1 gene mutation Złotnicka pig population. For the Zlotnicka White sow population, a statistically significant effect of the Gh/Mspl genotype on the litter body weight at day 21 was observed. The genotype frequencies of LEP indicate that the number of TT genotype individuals was very small in the Zlotnicka White pig population. Among Zlotnicka Spotted pigs, no TT genotype individuals were noted. In the analysed Zlotnicka pig population, no statistically significant genotype effect, concerning the LEP gene, on reproductive traits was observed.

\section{References}

1. Buczyński J. T., Panek A., Kempisty B.: Studies of growth hormone gene polymorphisms in Zlotnicka pig populations. Ann. Anim. Sci. 2006c, 2, 15-19.

2.Buczyński J. T., Panek A., Kempisty B., Skrzypczak E., Luciński P.: Reproductive performance of Zlotnicka White pigs as related to RYR1 gene. Anim. Sci. Pap. Rep. 2006b, vol. 24, 43-50.

3. Buczyński J. T., Panek A., Kempisty B., Szulc K., Luciński P.: An attempt at determining the effect of point mutation in gene RYR1 on reproductive performance of Zlotnicka Spotted pigs. Anim. Sci. Pap. Rep. 2006a, 24, 35-41.
4. Buczyński J. T., Szulc K.: Progress in the restitution of the Zlotnicka pig. Ann. Anim. Sci. 2001, Suppl. No. 1, 161-163.

5. De Oliveira Peixoto J., Facioni Guimarães S. E., Sávio Lopes P., Menck Soares M. A., Vieira Pires A., Gualberto Barbosa M. V., De Almeida Torres R., De Almeida e Silva M.: Associations of leptin gene polymorphisms with production traits in pigs. J. Anim. Breed. Genet. 2006, vol. 123, 378-383.

6. Franco M. M., Antunes R. C., Silva H. D., Goulart L. R.: Association of PIT1, GH and GHRH polymorphisms with performance and carcass traits in Landrace pigs. J. Appl. Genet. 2005, 46, 195-200.

7. Hamilton D. N., Ellis M., Miller K. D., McKeith F. K., Parrett D. F.: The effect of the Halothane and Rendement Napole genes on carcass and meat quality characteristics of pigs. J. Anim. Sci. 2000, 78, 2862-2867.

8. Hu L. Z., Park C. A., Fritz E. R., Reecy J. M.: QTLdb: a comprehensive database tool building bridges between genotypes and phenotypes. The $9^{\text {th }}$ World Congress on Genetics Applied to Livestock Production. Leipzig, Germany, August 1-6, 2010.

9. Jankowiak H., Kapelański W., Wilkanowska A., Cebulska A., Biegniewska M. The effect of CLPS and RYR1 gene polymorphism on meat quality of Zlotnicka spotted pigs. Journal of Central Europ. Agric. 2010, 11, 93-98.

10. Kennes Y. M., Murphy B. D., Pothier F., Palin M. F.: Characterization of swine leptin (LEP) polymorphisms and their association with production traits. Anim. Genet. 2001, 32, 215-218.

11. Kuryt J., Kapelański W., Pierzchała M., Bocian M., Grajewska S.: A relationship between genotypes at the GH and LEP loci and carcass meat and fat deposition in pigs. Anim. Sci. Pap. Rep. 2003, 15-26.

12. Lechniak D., Long S. E., Nissen A. K.: Distribution of polymorphic forms at the porcine $\mathrm{GH}$ locus in the population of day-10 pig embryos. J. Appl. Genet. 2002, 43, 93-96.

13. Matoušek V., Kernerová N., Kolařiková O., Kř̌žová H., Urban T., Vrtková I.: Effect of RYR1 and ESR genotypes on the fertility of sows of Large White breed in elite herds. Czech J. Anim. Sci. 2003, 48, 129-133.

14. Pierzchała M., Blicharski T., Kuryt J.: Growth rate and carcass quality in relation to $\mathrm{GH} / \mathrm{MspI}$ and $\mathrm{GH} / \mathrm{HaeII}$ PCR-RFLP polymorphism in pigs. Anim. Sci. Pap. Rep. 2004, 22, 57-64.

15. Pripwai N., Mekchay S.: Haplotype Analysis of Ferritin Heavy Chain Affects Stillborn Piglets on Large White X Landrace Crossbred Sows. J. Agr. Sci. 2012, 4, 62-70.

16. Rybarczyk A., Kmieć M., Karamucki T., Terman A.: Association of growth hormone $(\mathrm{GH})$ gene polymorphism with carcass and meat quality traits in PIC hybrid pigs. Arch. Tierz., Dummerstorf 50, Special Issue 2007, 205-213.

17. Rybarczyk A., Kmieć M., Szaruga R., Polasik D., Terman A., NatalczykSzymkowska $W$ : Leptin Gene (Lep) Polymorphism in PIC Hybrid Fatteners Free From Stress Susceptibility Gene (RYR1 ${ }^{\mathrm{t}}$ ). Electronic J. Polish Agric. Univ. 2010, 13, http://www.ejpau.media.pl/volume13/issue3/art-07.html

18. SAS.: Guide for Personal Computers, ver. 9.2. SAS Inst. Inc., Cary, NC, USA 2009.

19. Skrlep M., Kavar T., Candek-Potokar M.: Comparison of PRKAG3 and RYR1 gene effect on carcass traits and meat quality in Slovenian commercial pigs. Czech J. Anim. Sci. 2010, 55, 149-159.

20. Soetan K. O., Salako A. E.: The importance of genetics in the diagnosis of animal diseases - A review. Afr. J. Biotechnol. 2010, 9, 402-408.

21. Terman A.: Effect of the polymorphism of prolactin receptor (PRLR) and leptin (LEP) genes on litter size in Polish pigs. J. Anim. Breed Genet. 2005, $122,400-414$.

22. Żebrowska T.: Leptin - a hormone of multifaceted action in animals. Adv. Agric. Sci. 2004, 111-122.

23. Żuk B.: Biometria stosowana. PWN, Warszawa 1989.

Corresponding author: dr inż. Jolanta Różańska-Zawieja, ul. Wolyńska 33, 60-637 Poznań, Poland; e-mail: jolek@up.poznan.pl 